\title{
РАЗДЕЛХУІ. АРХИТЕКТУРА
}

\author{
Ольхин Ю.В., Селиверстов А.А. \\ Малые архитектурные формы в композиции ландшафтного дизайна, озеленения и \\ благоустройства общественных пространств \\ ФГБОУ ВО Петрозаводский государственный университет (ПетрГУ)
}

(Россия, Петрозаводск)

doi: $10.18411 / \mathrm{j}-09-2018-84$

idsp: 000001:lj-09-2018-84

\section{Аннотация}

В статье сообщается о проектной деятельности в ПетрГУ в рамках Программы развития опорного университета на 2017-2021 гг. Студенты и преподаватели в рамках учебной и проектной деятельности Института лесных, горных и строительных наук ПетрГУ принимают участие в разработке проектов для различных объектов ландшафтной архитектуры и изготовлении малых архитектурных форм.

Ключевые слова: опорный университет, дизайн-проект, объекты ландшафтной архитектуры, малая архитектурная форма, ландшафтный дизайн, озеленение

В Петрозаводском государственном университете с 2017 года реализуются стратегические проекты, направленные на создание системных элементов комфортной и креативной среды - малых архитектурных форм, ландшафтного благоустройства и экологического дизайна на университетских и муниципальных территориях в Республике Карелия. Проекты «Новое пространство: инженерно-технические решения для создания малых архитектурных форм на университетских территориях, включая территорию кампуса» и «Инновационные решения для формирования комфортной и креативной среды в регионе» выполняются при поддержке Программы развития опорного университета на 2017-2021 гг.

Результаты работы стратегических проектов способствуют, как формированию современного образа университета, так и ландшафтно-эстетическому обогащению территорий элементами комфортной и креативной среды.

Активное участие в проектной деятельности принимают студенты и преподаватели Института лесных, горных и строительных наук (ИЛГСН) ПетрГУ. Проводится работа по сбору необходимого для проектирования материала, проведения инвентаризации насаждений, разработке проектов для различных объектов ландшафтной архитектуры и их отдельных узлов (детских игровых площадок, спортивных площадок, площадок для отдыха, прогулочных маршрутов, растительных композиций и др.).

Одним из важных результатов проектной работы по программе «Формирование комфортной городской среды» стала разработка дизайн-проекта парка 50-летия пионерской организации г. Петрозаводска с учетом требований доступной среды для маломобильных групп населения. Дизайн-проект парка 50-летия пионерской организации был представлен 18 марта 2018 года в рейтинговом голосовании по программе «Формирование комфортной городской среды» (рис. 1).

Дизайн-проект занял 2 место в рейтинговом голосовании. Работы по реализации отдельных проектных решений проводились летом 2018 подрядчиками, выигравшими тендер и утвержденными администрацией города. 


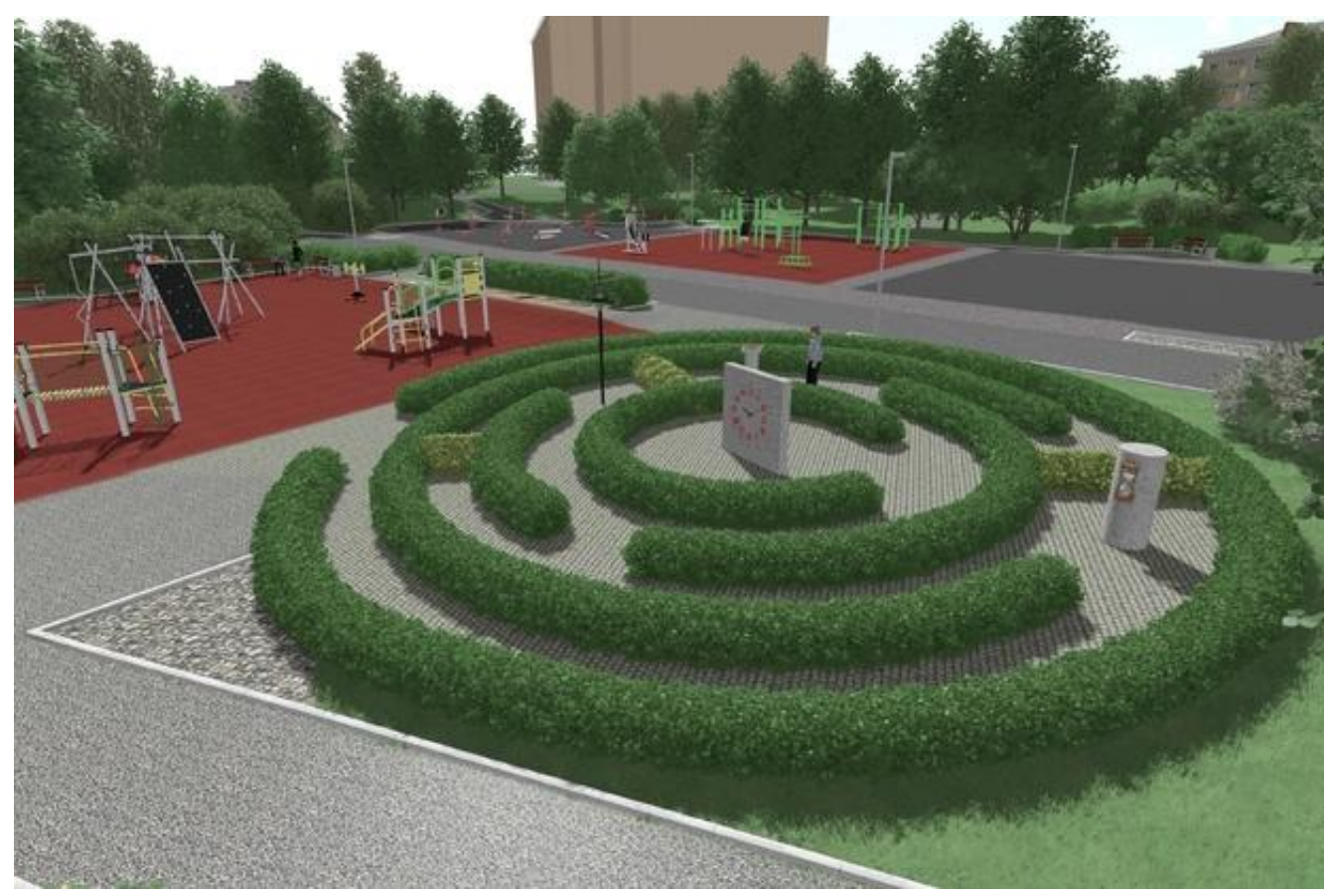

Рис. 1. 3D-визуализачия для дизайн-проекта парка 50-летия пионерской организации г. Петрозаводска

В 2018 году совместная проектная работа преподавателей и студентов проводится для объектов ландшафтной архитектуры (дворовых территорий, школьных участков, парков) в населенных пунктах Республики Карелия, а именно:

- выполнение инвентаризации насаждений и анализ состояния деревьев и кустарников парка в пос. Лоухи (сентябрь-октябрь 2018);

- инвентаризация насаждений и анализ состояния деревьев и кустарников на территории зоны отдыха в пос. Толвуя (сентябрь-октябрь 2018);

- выполнение инвентаризации насаждений и анализ состояния деревьев и кустарников на территории СОШ №8 г. Петрозаводска (сентябрь-октябрь 2018);

- инвентаризация насаждений и анализ состояния деревьев и кустарников на территории парка в г. Олонец (сентябрь-октябрь 2018);

- выполнение инвентаризации насаждений и анализ и состояния деревьев и кустарников на территории парка в пос. Гирвас (сентябрь-октябрь 2018);

- инвентаризация насаждений и анализ состояния деревьев и кустарников на территории общественного пространства в г. Костомукша (сентябрьоктябрь 2018);

- выполнение инвентаризации насаждений и анализ состояния деревьев и кустарников на территории промышленного предприятия в г. Кондопога (сентябрь-октябрь 2018);

- выполнение инвентаризации насаждений и анализ состояния деревьев и кустарников на территории средней общеобразовательной школы в пос. Деревянка (сентябрь-октябрь 2018);

- выполнение инвентаризации насаждений и анализ состояния деревьев и кустарников на территории общественного центра в пос. пос. Волома Муезерского района (сентябрь-октябрь 2018) и для других районов Республики Карелии.

К сожалению, в реализации проекта «Формирование комфортной городской среды» основное внимание сосредоточено на благоустройстве территорий, организации 
детских, спортивных площадок, устройстве мест отдыха, а формированию растительных композиций уделяется недостаточное внимание. Таким образом, мы рассматриваем вопросы организации пространства комплексно, когда элементы комфортной и креативной среды - малые архитектурные формы органично вписывались бы в композиции ландшафтного дизайна, озеленения и благоустройства.

Студенты ИЛГСН принимают непосредственное участие и в изготовлении разрабатываемых малых архитектурных форм, получая ценный опыт в ландшафтной архитектуре и области промышленного дизайна (рис. 2).

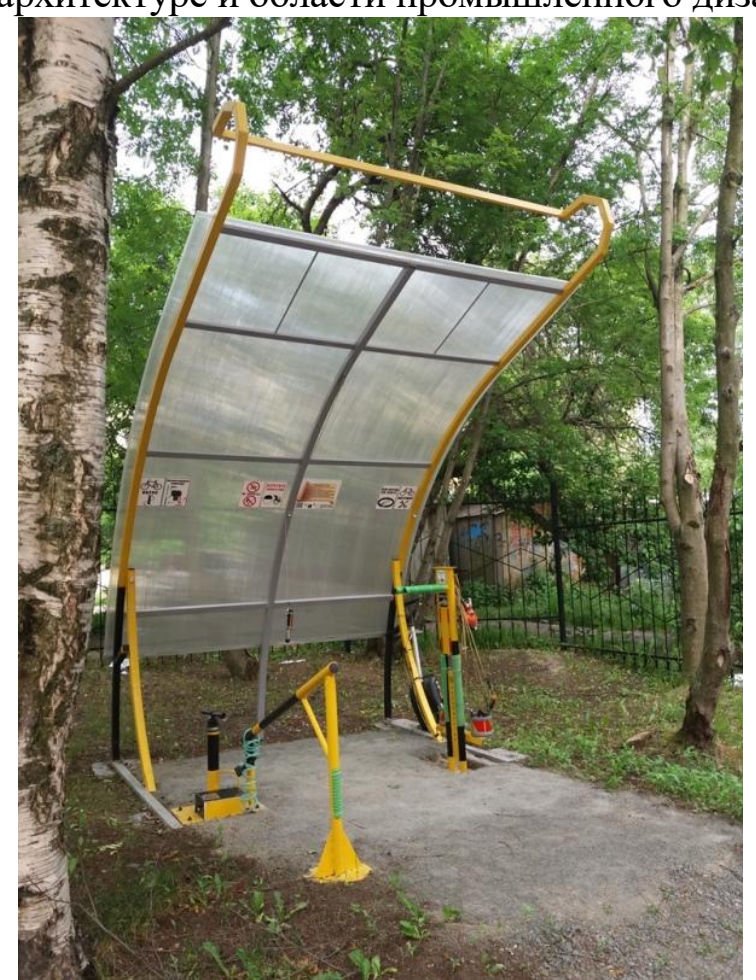

Рис. 2. Бесплатная сервис-станция для велосипедов «Вело-питстоп» на территории главного корпуса ПетрГУ

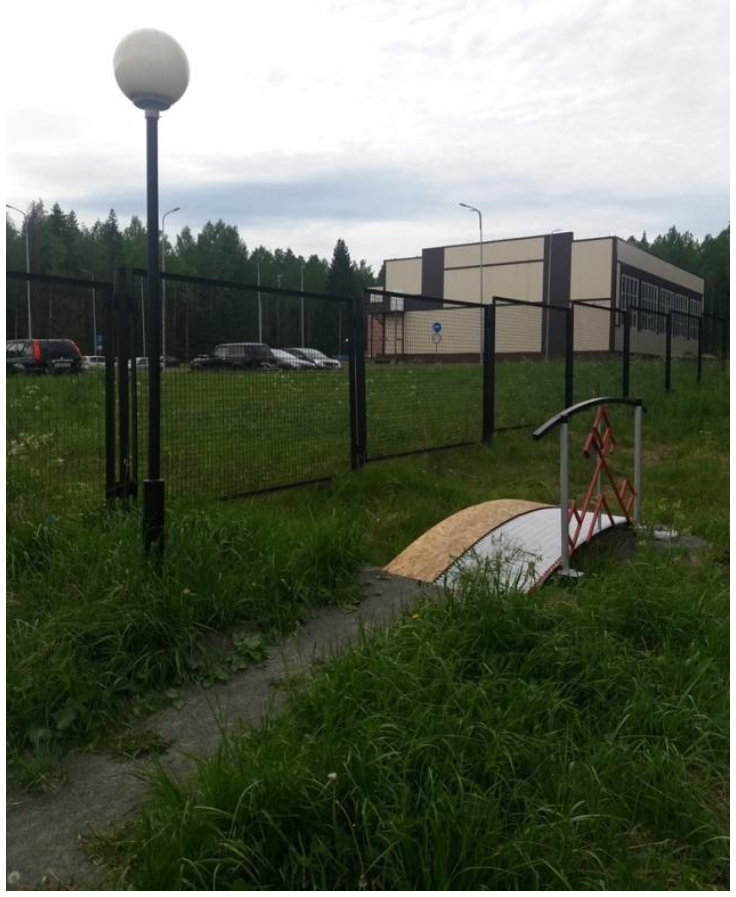

Рис. 3. Металлический мостик «Соединение пространств», кампус ПетрГУ

При проектировании малых архитектурных форм наряду с их утилитарным назначением уделяется внимание эстетической стороне (рис.3).

Рассматривая дворовые и общественные территории, которые участвуют в программе «Формирование комфортной городской среды», большой декоративный интерес представляют группы деревьев и кустарников. Группы могут быть разнообразными по многим характеристикам: по составу, по количеству экземпляров, по условиям обзора, по динамике и т. д. При этом зеленые насаждения играют роль фона для малых архитектурных форм, выделяя их архитектурно-художественные достоинства, либо малые архитектурные формы связаны с природным окружением для создания своеобразного ландшафта. Также все системные элементы пространственной среды отвечают единому замыслу.

При проектировании растительных групп, их композиционного построения мы, прежде всего, выбирали главное, акцентные и фоновые растения. Главное растение должно выделяться в группе во все сезоны. Поэтому при подборе мы обращали внимание на высоту, контурную и объемную формы, а также структуру ветвления, цвет, текстуру кроны. Растения-акценты в группе должны обладать выраженными сезонными изменениями декоративных качеств. Роль акцентов в композиции очень значима, т.к. они проявляют свои декоративные качества и привлекают внимание наблюдателя в определенный период времени. При этом декоративные качества акцентов могут быть разными, как и длительность их действия. Определенные деревья и кустарники являются 
акцентом в течение непродолжительного периода и большую часть времени выполняют функцию фонового растения. Например, сирень обыкновенная благодаря цветению становится прекрасным акцентом в конце мая - середине июня, но в остальное время у нее нет ярких декоративных качеств, поэтому в композиции она будет выполнять функцию фона. В качестве декоративных акцентов в группах, для визуального разделения пространства, для оформления развилок, поворотов маршрутов мы проектировали преимущественно кустарники.

Кустарники обладают большим разнообразием декоративных качеств, а их размеры способствуют формированию пропорциональных масштабу человека композиций и пространств. Кроме того, декоративные качества кустарников, а именно яркое и длительное цветение, яркая листва сортовых форм имеют и функциональное значение. Такие растения были запроектированы нами в группах на поворотах и развилках дорог для улучшения визуальной ориентации посетителей, в том числе людей с ослабленным зрением. Конечно такие группы использовались в качестве дополнения к основным приемам, включающим применение контрастных бордюров и различных фактур покрытий дорог.

На 2019 год запланировано продолжение работы с участием студентов по изготовлению оригинальных малых архитектурных форм с выполнением проектов озеленения и благоустройства для 20 общественных территорий в городе Петрозаводске и населенных пунктах в районах Республики Карелия.

$$
* * *
$$

1. В ПетрГУ появится свой «Вело-питстоп». [Электронный ресурс]. URL: https://petrsu.ru/news/2017/37551/v-petrgu-poyavitsya- (дата обращения: 26.09.2018).

2. Здесь будет дивный сад! [Электронный ресурс]. URL: https://petrsu.ru/news/2018/40336/zdes-budetdivnyi-sa (дата обращения: 27.09.2018).

3. Новый архитектурный объект появился в Петрозаводске. [Электронный ресурс]. URL: https://kareliyanews.ru/novyj-arxitekturnyj-obekt-poyavilsya-v-petrozavodske-foto/ (дата обращения: 28.09.2018).

4. Ольхин Ю.В. Опыт разработки дизайн-проектов общественных территорий г. Петрозаводска в рамках программы "Формирование комфортной городской среды" / Ю.В. Ольхин // Повышение эффективности лесного комплекса: материалы четвертой Всероссийской научно-практической конференции с международным участием. Петрозаводск, 2018. С.127-128.

5. Перский С.Н. Создание объектов малой архитектурной формы на территории университета [Электронный ресурс] / С.Н. Перский, А.А. Селиверстов // Инновационное развитие. Пермь, 2017. №12 (17). C.83-85. URL: https://научный-сборник.pф/arhiv-ir/ (дата обращения: 28.09.18).

\section{Семенюк О.Н. Экология города}

doi: $10.18411 / \mathrm{j}-09-2018-85$

ЕНУ им. Л.Н. Гумилева

(Казахстан, Астана)

idsp: 000001:lj-09-2018-85

\section{Аннотация}

Экология города решает социально-экологические проблемы больших застроенных территорий, изучает взаимодействие городов и систем расселения с природной средой с учетом возможных пределов и последствий изменений, вызываемых этим процессом.

Ключевые слова: экология, городская застройка, экосистема, градостроительная среда, природная среда. 